\title{
Karakoyunlular Akkoyunlular-İran ve Anadolu'da Türkmen Hanedanları
}

\section{Muhsin Behrâmnejâd, Tercüme ve Notlar: Serdar Gündoğdu- Ali İçer, İstanbul: Kronik Kitap, 2019. ss. 144, ISBN: $\mathbf{9 7 8 6 0 5 7 6 3 5 2 8 0}$}

Değerlendiren: Seyhan Dobra*

\author{
Kim ki bilmez öz hakkun zâtını, \\ Sormagil andan anun isbâtını; \\ Oynamaz şatranc-ı ışkun atını, \\ Görmeyen bu rukanun şeh-mâtını
} (Hakîkî)

Eser incelememize konu olan Karakoyunlular (1351-1469), başkenti Tebriz olan ve Doğu Anadolu, Azerbaycan, İran ve Irak'ta hüküm süren bir Türkmen hanedanıdır. Akkoyunlular (1340-1514) ise Horasan'dan Firat Irmağı'na ve Kafkas Dağları'ndan Umman Denizi'ne kadar olan topraklarda egemen olmuş Oğuz Türklerinin kurmuş olduğu bir devlettir. Takrîben 14. yüzyıl ortalarında İran ve Doğu Anadolu'nun doğusunda teşekkül eden bu iki devletin siyasi hayatları birbirleriyle hâkimiyet mücadelesi ile geçmiştir. Öyle ki bahsi geçen bu iki devlet arasındaki rekâbet Türkmen halk efsanelerine dahi konu olmuştur. Karakoyunlular ve Akkoyunlular hüküm sürdükleri yıllarda çoğunlukla İlhanlılar sonrası Moğol bakiyeleriyle mü-

Doktora Öğrencisi, Bolu Abant İzzet Baysal Üniversitesi, Fen Edebiyat Fakültesi, Tarih Bölümü, Bolu, Türkiye, seyhandbra@hotmail.com, ORCID: 0000-0002-46116135 
cadeleleri ile yaşam sahalarını genişletme yoluna gitmişlerdir. Anadolu ve İran coğrafyasının Türkleşmesini sağlayan Karakoyunlu ve Akkoyunlu devletleri, tarih sahnesinde sadece çekişmeli siyasi yaşamlarıyla değil aynı zamanda ilme, sanata ve âlime teveccüh gösteren yönleriyle de varlık göstermişlerdir. Bu Türkmen hanedanları yaşadıkları devirde ilmî, içtimâî ve kültürel pek çok gelişmeye öncülük etmişlerdir.

Bahsi geçtiği üzere çok yönlü faaliyetleriyle tarihin belli bir dönemin etkisi altına alan Karakoyunlu ve Akkoyunlu devletleri üzerine Türkiye'de çok sayıda kitap yazıla gelmiştir. Konuya dair özellikle sahanın önemli âlimlerinden Mükrimin Halil Yinanç, Faruk Sümer ve İsmail Aka'nın nitelikli ve de kapsamlı çalışmaları dikkat çekmektedir. Bu çalışmaların mevcudiyetine rağmen yine de Karakoyunlu ve Akkoyunlu devletlerinin özellikle siyasi oluşum süreçlerini kısa ve öz mahiyette ele alan bir çalışma ihtiyacı hissedilmiştir. Bu ihtiyaç Muhsin Behrâmnejâd'ın birinci el kaynaklardan yaralanarak vücuda getirdiği Karakoyunlular ve Akkoyunlular adlı eseriyle giderilmeye çalışılmıştır. Tanıtımımıza konu olan bu eser yazılırken İran'da dönemin önemli kaynak eserleri dikkate alınmıştır. Bu kaynaklardan ilki Ebu Bekir Tihranî İsfahanî’nin Akkoyunlu Uzun Hasan'ın telkinleriyle kaleme aldığı, Akkoyunlu tarihini iki esas bölümde ele alan kitab1 Kitâb-1 Diyârbekriyye'dir. Bir diğer çalışma, Fazlullah Rûzbihân Huncî İsfahânî'nin Akkoyunlu Devleti temelinde ele almasının yanı sıra Azerbaycan, Gürcistan, Fars, Kirman vb. bölge tarihlerine yer verdiği Târîh-i Âlem-Ârâ-yi Emîn-î 'dir. Son olarak, Budak Münşî-yi Kazvînî’nin genel bir tarih kitabı olan ve muhtevâsının bir bölümünde Karakoyunlu ve Akkoyunlu tarihine yer verdiği Cevâhirü'l-Ahbâr isimli eseridir.

Müellif Behrâmnejâd'ın yazmış olduğu Karakoyunlular ve Akkoyunlular adlı eser iki bölümden müteşekkildir. Eserin bölümlerine girizgâh yapılmadan önce çalışma kaleme alınırken yararlanılan ve yukarıda da adı geçen üç önemli ana kaynağın içeriği ve müelliflerine dâir biyografik mâhiyette bilgiler verilmiştir. Kitabın birinci bölümünde, Karakoyunlu hanedanı tarihi ele alınmıştır. Bu bölümün alt başlıklarında Karakoyunlu siyasi tarihi kısa başlıklar halinde irdelenmiştir. Sırasıyla Karakoyunlu Kara Mehmed'den başlayarak, Kara Yusuf'tan Mirza Cihan Şah'a kadar devlete hükümdarlık etmiş şahsiyetlerin, devletin bekâsı ve sınırların muhafazası için giriştiği siyasi mücadeleler ilk bölümün ana temasını oluşturmuş̧tur.

Kitabın ikinci bölümünde ise, Akkoyunlu devleti hakkında bilgilere değinilmiştir. Akkoyunlu hanedanının kurucusu Uzun Hasan'ın soyu ve atala- 
rından başlayıp kronolojik olarak hükümdarların saltanat yılları temelinde fetihlere, isyanlara, muhtelif devletlerle yaptıkları savaşlara, antlaşmalara dair genel olarak bilgilendirme yapılmıştır. Kitapta her iki bölümün nihayetinde bu iki devlete ait soy ağacına yer verilmiştir. Çalışma kapsamında yararlanılan kaynaklar ve indeks ile çalışma sonlandırılmıştır. Muhsin Behrâmnejâd'ın kaleminden çıkan bu çalışma, tarihçi Serdar Gündoğdu ve Ali İçer 'in tercüme ve notlandırmasıyla okuru ile buluşmuştur.

$\mathrm{Bu}$ eseri Karakoyunlu ve Akkoyunlulara dair yapılagelen diğer çalışmaların berisinde tutan bir özelliği de sadeliği öngörmesi ve özü yansıtması olmuştur. Bahsi geçen eserin ana konusu olan bu iki Türkmen hanedanı, İran'da Safevî devletinin kurulmasına ve günümüzde özellikle Iğdır ve Kars yöreleri başta olmak üzere Doğu Anadolu'da, İran ve Azerbaycan'da doğu Oğuz ve Türkmen lehçesi olarak bilinen Azerbaycan Türkçesinin de yaygınlık kazanmasına katkıda bulunmuşlardır. Dolayısıyla bu çalışma vesilesiyle satır aralarında sadece bu devletlerin klasik tarzda işlenmiş siyasi oluşum sürecini değil bununla birlikte çok yönlü kültür yapılanmalarını da görebilmek mümkün olacaktır. Dilinden de fark edileceği üzere, eser akademik camiadaki kişilerin yanında tarihe ilgi duyan sade kişilerin de anlayabileceği bir lisaniyatta yazılmıştır. Bu bağlamda kitap, gerek konuyla ilintili araştırma yapmak isteyenler için gerekse merak duygusuyla bu iki Türkmen devletini yakından tanımak isteyen kimseler için bir başvuru eseri mâhiyetindedir. Nihâî olarak; Muhsin Behrâmnejâd'ın hacimce dar ancak mânâ olarak kapsamlı bu eserinde okur, İran topraklarından Anadolu'ya uzanan süreçte Karakoyunlu ve Akkoyunlu devletlerinin siyasi eksenli hikâyesini kapsayıcı ve bir o kadar da yalın sesiyle inceleme imkânı bulacaktır. 